\title{
Studying soil-reclamation state of rice agricultural landscapes
}

\author{
Nadezhda Malysheva ${ }^{1,}$ Sergey Kizinek ${ }^{2}$, Anna Khadzhidi $^{1}$, Lyudmila Kravchenko ${ }^{3 *}$, \\ Valeriia Chegge $^{3}$, Dzhuletta Sarkisian ${ }^{3}$, and Sirun Saakian ${ }^{3}$ \\ ${ }^{1}$ Kuban State Agrarian University named after I.T. Trubilina, 350044, 13, Kalinina str, Krasnodar, \\ Russia \\ ${ }^{2}$ Rice breeding plant "Krasnoarmeisky" them. A.I. Maistrenko \\ ${ }^{3}$ Don State Technical University, 344003, 1. Gagarin sq., Rostov-on-Don, Russia
}

\begin{abstract}
The article presents studies of the soil-reclamation state of rice agricultural landscapes of Krasnodar Territory using the example of the Chernoyerovskaya irrigation system. The direction of changes in soil salinity over a long-term period was revealed. In the framework of monitoring the state of rice soils, salt survey was carried out. The degree, type and causes of their salinization have been determined, the relationship between the salt regime of soils and the regime of the level and chemical composition of groundwater has been established. Recommendations for managing the fertility of rice agricultural landscapes are given.
\end{abstract}

\section{Introduction}

The reclamation complex of Kuban is represented by twelve rice irrigation systems with the total area of 234.4 thousand hectares, which are used in crop production and are integral part of the agro-industrial complex of the Krasnodar Territory [1].

The rice irrigation systems of Krasnodar Territory are located mainly in the places of the former floodplains of Lower Kuban, which were not previously used for the cultivation of crops. These were large land tracts with marsh soils, that were heavy in texture, often mineralized with high salt content, unsuitable for agricultural production. The indicated areas represented certain landscapes formed under the influence of natural factors. [2].

The construction of irrigation systems with the movement of large soil volumes, agricultural activities, and especially rice cultivation, where rice cultivation technology is associated with the presence of water layer in the field for three months a year, transformed natural landscapes into agricultural landscapes, characterized by fairly large variety of soils, mesorelief forms, geochemical, hydrochemical and other indicators [3-4].

In Lower Kuban, the main subtypes of rice soils are meadow-chernozemic, meadow, alluvial meadow-marshy, characteristic feature of which is compaction, merging and salinity $[5,6]$. Some of these soils (about 15\%) are saline, which is associated with the hydrological regime during the growing season, the close occurrence of groundwater and

\footnotetext{
*Corresponding author: lusya306@yandex.ru
} 
their high mineralization due to the proximity of the Azov Sea. Rice cultivation on such soils contributes to their stratification and involvement in agricultural circulation [7].

At present, despite the intensification of agricultural production and the successful cultivation of rice and rice crop rotation in the irrigation systems of the region, the problem of soil salinization in rice agricultural landscapes, caused by groundwater salinity, remains relevant, which requires the development of measures that contribute to the management of soil fertility in order to increase productivity and of gross harvest of rice grain.

Therefore, the main purpose of these studies is to investigate the soil-reclamation state of irrigated lands using the example of Chernoerkovsk irrigation system, located in the Slavyansky district of Krasnodar Territory, to ensure the food security of the region, as well as to develop set of measures to prevent soil degradation and their removal them from agricultural circulation. The achievement of this goal is ensured by solving the problems of assessing the hydrogeological-reclamation situation with the establishment of stationary wells to study the groundwater depth, conduct their chemical analysis, determine the degree of salinity and alkalinity of soils, and develop recommendations for regulating the soil fertility of rice agricultural landscapes.

\section{Material and methods}

To study changes in soil salinity over a long-term period (1977-2019) on Chernoerkovskaya irrigation system, cameral work was carried out on retrospective analysis of indicators of groundwater occurrence depth and mineralization. There were used materials of the annual technical reports of the "Management of land reclamation and agricultural water supply on Krasnodar Territory" organization that is operating melioration systems.

To monitor hydrological and reclamation state of irrigated lands before the beginning of the irrigation period (April-May) and after its end (September-November), temporary wells were drilled up to $1 \mathrm{~m}$ deep (one well per 150 hectares of irrigated land) on Chernoerkovsk irrigation system. The selection of soil samples was carried out at intervals of 0-25 cm, 25-50 $\mathrm{cm}$. Drilling of wells was accompanied by hydrogeological observations of the salt regime of soils. Salt sampling and determination of the soil salinity degree in the surveyed massif were carried out according to the standards [8]. In the selected patterns and samples, the following analyzes were performed: water extract; the absorbed sodium and the absorbed bases are determined. The method is based on the extraction of soluble salts from the soil by water at soil:water ratio of 1:5, followed by determination of $\mathrm{CO}_{3}, \mathrm{HCO}_{3}, \mathrm{Cl}, \mathrm{Ca}, \mathrm{Mg}$, $\mathrm{Na}, \mathrm{SO}_{4}$ ions in the studied aqueous extract [9]. Determination of sodium is carried out on flame photometer (Figure 10), spraying the analyzed extracts into the flame. The sodium content in the analyzed soils is found on the working scale of standard solutions in mg-eq per $100 \mathrm{~g}$ of soil.

After finishing laboratory work, all identified saline soils were systematized according to depth intervals, salt accumulation intervals, and type and degree of salinity.

\section{Results and discussion}

The Chernoerkovskaya irrigation system has been exploited since 1977, at present it is located on total area of 33.2 thousand hectares, and is the most typical in terms of soil conditions for the western natural and climatic zone of Krasnodar Territory. In terms of geomorphological zoning, it is part of the Kuban delta-flooded region, and its northern part is located on the territory of the Azov Plains subdistrict, and its large southern part is located on the territory of the transitional region to Old Delta. On Chernoerkovskaya rice 
irrigation system, humus-gley, peat-gley and meadow-bog soils with close occurrence of groundwater and their high mineralization are widespread, which have undergone significant changes since 1997 under the influence of constant flooding during the growing season of rice [10].

Retrospective analysis revealed that decrease in the groundwater salinity and downgrade in its level occurred gradually, which was facilitated by the percolative regime of soils under the rice crop and the year-round operation of the collector-drainage network. So, at the beginning of exploitation in 1997, the groundwater occurrence of $0.92 \mathrm{~m}$ that is very close to the soil surface, was observed, and their mineralization was $10.2 \mathrm{~g} / \mathrm{l}$. With further operation, significant decrease in the above indicators was observed only after 10 years by 1986 (Fig.1).

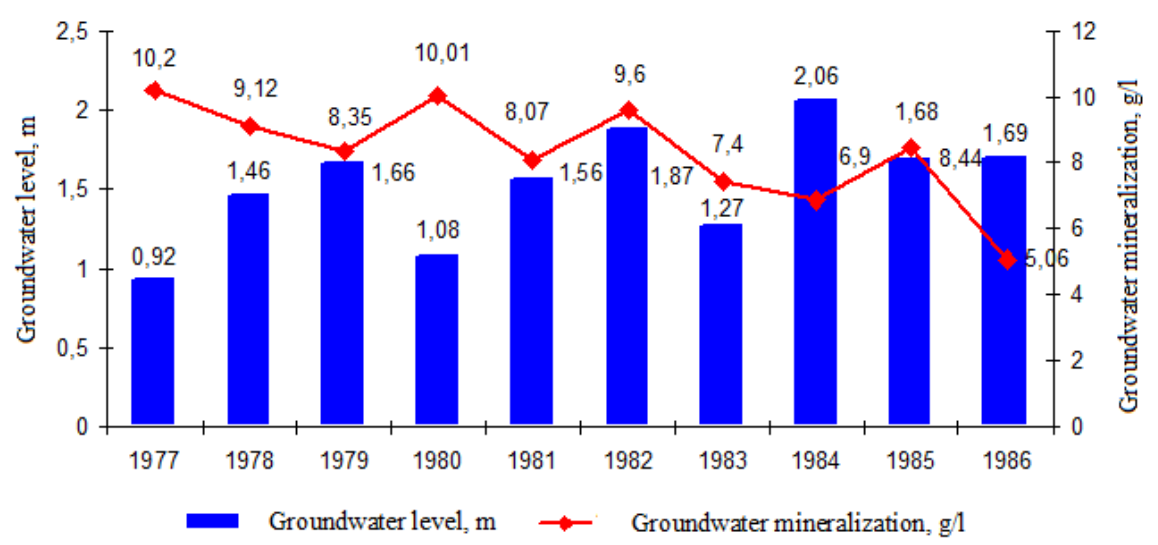

Fig. 1. Groundwater level and mineralization on the Chernoerkovskaya irrigation system, 1977-1986

From 1986 to 2001, groundwater was at $1.49 \mathrm{~m}$, and their salinity averaged $5.02 \mathrm{~g} / 1$ for the indicated period.

A further decrease and stabilization of the groundwater level at elevations of 1.41-1.62 $\mathrm{m}$ was observed from 2002 to the present. At the same time, the indicators of groundwater salinity were lower than in the previous period and amounted to about 4.46-4.76 g / 1 (Fig. 2).

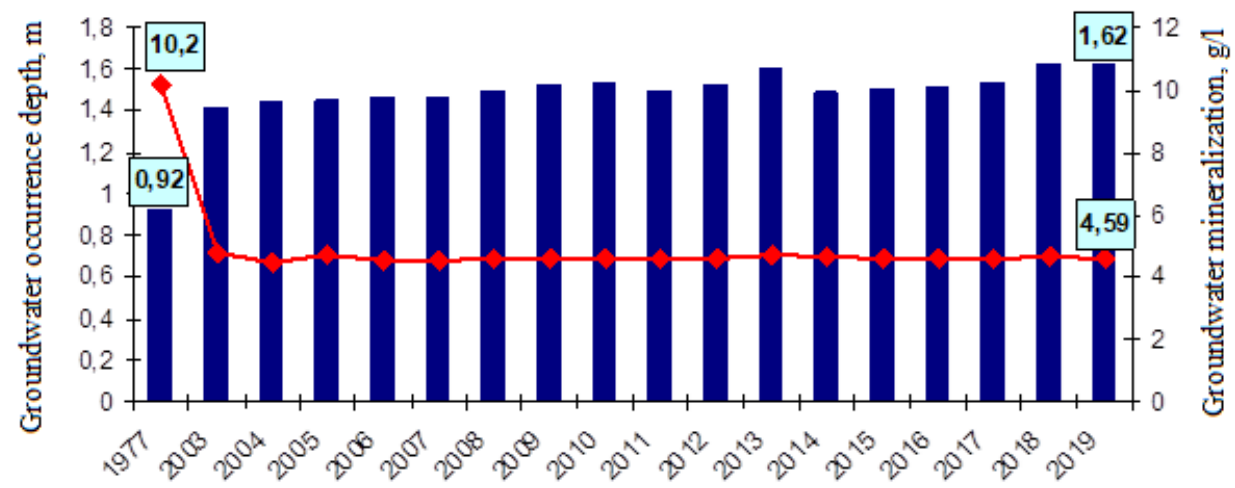

Groundwater level, $\mathrm{m} \rightarrow$ Groundwater mineralization, $\mathrm{g} / \mathrm{l}$ 
Fig. 2. Groundwater level and mineralization in the Chernoerkovsk irrigation system, 2003-2019 in comparison with 1977

Thus, retrospective analysis of the indicators of groundwater mineralization revealed their significant salinity since the beginning of the operation at Chernoerkovsk irrigation system (1977), which equaled to $10.2 \mathrm{~g} / \mathrm{l}$. Over the course of 42 years of land exploitation for growing rice and related crops of crop rotation, this indicator has stabilized since 2002 at $4.46 \mathrm{~g} / 1-4.76 \mathrm{~g} / \mathrm{l}$, which is caused by the percolative regime of soils and proves once again the need to grow rice in the crop rotation system as ameliorant.

In order to monitor the hydrological and reclamation state of Chernoerkovsk irrigation system in the period of 2017-2019 salt survey was carried out. It was found that the groundwater opening at Chernoerkovsk irrigation system on average over the past three years (2017-2019) was within $1.62 \mathrm{~m}$ and ranged from $0.93 \mathrm{~m}$ (well no. 75 ) to $2.77 \mathrm{~m}$ (well no. 42, 48). By the occurrence depth of groundwater in 2019 , the system areas were distributed in the following order: less than $1.0 \mathrm{~m}-378$ hectares $(1 \%$ of the total area of the system); from $1.0 \mathrm{~m}$ to $1.5 \mathrm{~m}-11187$ ha (34\%); from $1.5 \mathrm{~m}$ to $2.0 \mathrm{~m}-18,079$ ha $(54 \%)$; from $2.0 \mathrm{~m}$ to $3.0 \mathrm{~m}-3194$ ha $(9 \%)$; from $3.0 \mathrm{~m}$ and more - 362 hectares (1\%) (Table 1).

Table 1. Occurrence depth of groundwater on the irrigated lands of Chernoerkovsk irrigation system, 2019

\begin{tabular}{|c|c|c|c|c|c|c|}
\hline \multirow{2}{*}{$\begin{array}{c}\text { Determination } \\
\text { place of } \\
\text { groundwater } \\
\text { level }\end{array}$} & \multirow{2}{*}{$\begin{array}{l}\text { Suspended } \\
\text { area, ha }\end{array}$} & \multicolumn{5}{|c|}{ Occurrence depth of groundwater, $\mathrm{m}$} \\
\hline & & $\begin{array}{c}\text { less than } \\
1.0 \mathrm{M} \\
\end{array}$ & 1.0-1.5 & $1.5-2.0$ & 2.0-3.0 & $3.0-5.0$ \\
\hline well no. 7 & 538 & 44 & 376 & 57 & 61 & - \\
\hline well no. $8-15$ & 14200 & 155 & 4238 & 8951 & 774 & 82 \\
\hline well no. $16-18$ & 5594 & 115 & 2394 & 2590 & 279 & 216 \\
\hline well no. $19-20$ & 1239 & - & - & 820 & 355 & 64 \\
\hline well no. 21 & 664 & - & - & 409 & 255 & - \\
\hline well no. 22 & 701 & - & 206 & 250 & 245 & - \\
\hline well no. $26-28$ & 2694 & 64 & 634 & 1801 & 195 & - \\
\hline well no. 29 & 854 & - & 150 & 601 & 103 & - \\
\hline well no. 30-34 & 4282 & - & 2274 & 1543 & 465 & - \\
\hline well no. 35 & 96 & - & 18 & 54 & 24 & - \\
\hline well no.38-45 & 2324 & - & 897 & 1003 & 424 & - \\
\hline well no. 48 & 14 & & & & 14 & - \\
\hline Всего & 33200 & 378 & 11187 & 18079 & 3194 & 362 \\
\hline
\end{tabular}

According to the chemical analysis results of ground waters, it was revealed that their average mineralization for the above period is $4.6 \mathrm{~g} / \mathrm{l}$. The area of surveyed irrigated land in 2019 with groundwater mineralization above $3 \mathrm{~g} / \mathrm{l}$ is 18.34 thousand hectares or $56 \%$ of the surveyed land, which characterizes them as highly salsuginous. On the rest of the area of 14.86 thousand hectares, the groundwater is salsuginous with mineralization of $1 \mathrm{~g} / 1$ to 3 $\mathrm{g} / \mathrm{l}$. Fresh waters with mineralization less than $1 \mathrm{~g} / \mathrm{l}$ were not found.[17-18]

The chemical composition of groundwater is diverse. Sulphate and sulphate-chloride waters are predominant.

Chloride-hydrocarbonate, chloride-sulphate, chloride, sulphate-hydrocarbonate, hydrocarbonate-sulphate, hydrocarbonate-chloride, hydrocarbonate ones are less developed (Table 2).

Table 2. Anionic-cationic composition of the water extract of the soils of Chernoerkovsk irrigation system, 2019 


\begin{tabular}{|c|c|c|c|c|c|c|c|c|}
\hline \multirow{2}{*}{$\begin{array}{c}\text { Sampling } \\
\text { location }\end{array}$} & \multirow{2}{*}{$\begin{array}{c}\text { Sampling } \\
\text { interval. cm }\end{array}$} & \multicolumn{4}{|c|}{ Anions } & \multicolumn{2}{|c|}{ Cations } & \multirow{2}{*}{$\begin{array}{c}\text { genera } \\
\% \text { of } \\
\text { salts }\end{array}$} \\
\hline & & $\mathrm{HCO}_{3}$ & $\mathrm{Cl}$ & $\mathrm{SO}_{4}$ & $\mathrm{Ca}$ & Mg & $\mathrm{Na}$ & \\
\hline \multirow{4}{*}{$\begin{array}{c}\text { well } \\
\text { no. } 38\end{array}$} & \multirow[t]{2}{*}{$0-25$} & 0.850 & 0.192 & 0.748 & 0.450 & 0.700 & 0.640 & \multirow{2}{*}{0.127} \\
\hline & & 0.052 & 0.007 & 0.036 & 0.009 & 0.009 & 0.015 & \\
\hline & \multirow{2}{*}{$25-50$} & 0.600 & 0.192 & 0.733 & 0.250 & 0.600 & 0.675 & \multirow{2}{*}{0.106} \\
\hline & & 0.037 & 0.007 & 0.035 & 0.005 & 0.007 & 0.016 & \\
\hline \multirow{4}{*}{$\begin{array}{c}\text { well } \\
\text { no. } 42\end{array}$} & \multirow{2}{*}{$0-25$} & 0.800 & 0.240 & 1.310 & 0.500 & 0.550 & 1.300 & \multirow[b]{2}{*}{0.167} \\
\hline & & 0.049 & 0.009 & 0.063 & 0.010 & 0.007 & 0.030 & \\
\hline & \multirow{2}{*}{$25-50$} & 1.000 & 0.192 & 1.358 & 0.400 & 0.450 & 1.700 & \multirow[b]{2}{*}{0.186} \\
\hline & & 0.061 & 0.007 & 0.065 & 0.008 & 0.005 & 0.039 & \\
\hline \multirow{4}{*}{$\begin{array}{c}\text { well } \\
\text { no. } 34\end{array}$} & \multirow{2}{*}{$0-25$} & 1.050 & 0.144 & 0.656 & 0.300 & 0.550 & 1.000 & \multirow[b]{2}{*}{0.136} \\
\hline & & 0.064 & 0.005 & 0.031 & 0.006 & 0.007 & 0.023 & \\
\hline & \multirow{2}{*}{$25-50$} & 1.250 & 0.144 & 0.706 & 0.200 & 0.400 & 1.500 & \multirow[b]{2}{*}{0.159} \\
\hline & & 0.076 & 0.005 & 0.034 & 0.004 & 0.005 & 0.035 & \\
\hline \multirow{4}{*}{$\begin{array}{c}\text { скв } \\
\text { no. } 48\end{array}$} & \multirow{2}{*}{$0-25$} & 1.000 & 0.240 & 0.910 & 0.350 & 0.650 & 1.150 & \multirow[b]{2}{*}{0.155} \\
\hline & & 0.061 & 0.009 & 0.044 & 0.007 & 0.008 & 0.026 & \\
\hline & \multirow{2}{*}{$25-50$} & 1.450 & 0.192 & 0.858 & 0.250 & 0.450 & 1.800 & \multirow[b]{2}{*}{0.188} \\
\hline & & 0.088 & 0.007 & 0.041 & 0.005 & 0.005 & 0.041 & \\
\hline \multirow{4}{*}{$\begin{array}{c}\text { well } \\
\text { no. } 20\end{array}$} & \multirow{2}{*}{$0-25$} & 0.150 & 0.192 & 0.338 & 0.150 & 0.350 & 0.180 & \multirow[b]{2}{*}{0.044} \\
\hline & & 0.009 & 0.007 & 0.016 & 0.003 & 0.004 & 0.004 & \\
\hline & \multirow{2}{*}{$25-50$} & 0.200 & 0.096 & 0.294 & 0.150 & 0.300 & 0.140 & \multirow[b]{2}{*}{0.040} \\
\hline & & 0.012 & 0.003 & 0.014 & 0.003 & 0.004 & 0.003 & \\
\hline \multirow{4}{*}{$\begin{array}{l}\text { well } \\
\text { no. } 27\end{array}$} & \multirow[t]{2}{*}{$0-25$} & 0.300 & 0.192 & 0.418 & 0.200 & 0.350 & 0.360 & \\
\hline & & 0.018 & 0.007 & 0.020 & 0.004 & 0.004 & 0.008 & 0.062 \\
\hline & $25-50$ & 0.300 & 0.144 & 0.756 & 0.200 & 0.500 & 0.500 & \\
\hline & & 0.018 & 0.005 & 0.036 & 0.004 & 0.006 & 0.012 & 0.081 \\
\hline
\end{tabular}

Analysis of Table 2 shows that, in terms of cationic composition, sodium and sodiummagnesium ground waters are mainly developed.

According to the results of the survey in 2019, it was revealed that soils on Chernoerkovsk irrigation system have different salinity degrees: there are 837 hectares of highly and very saline soils $(2 \%), 8742$ hectares of moderately saline soils $(26 \%), 10,093$ hectares of slightly saline soils (37\%), 11528 ha of non-saline soils $(35 \%)$.

According to the solonetzic content, the soils of the studied system are subdivided into non-solonetzic soils - 32120 ha $(97 \%)$ and weakly solonetzic soils - 1082 ha (3\%). No medium and strongly solonetzic soils were found. Summarizing the results of the comprehensive survey, it is possible to characterize the reclamation state of irrigated lands on Chernoerkovsk irrigation system. Out of the surveyed 33,200 ha, 7413 ha are in good condition, 8448 ha are in satisfactory ones. Areas with unsatisfactory condition amount to 17339 hectares, including 7760 hectares of unacceptable groundwater level, 5570 hectares of under salinization, 3709 hectares with unacceptable groundwater level.[19-20]

To improve hydrological and reclamation state of soils on the irrigated lands of Chernoerkovsk irrigation system, especially in areas with unsatisfactory indicators of reclamation status, to regulate their soil fertility, the following measures are required: repair planning of checks; arrangement of mole drainage and cutting of drainage furrows. For the cultivation of salt licks, it is recommended to carry out chemical reclamation in combination with organic fertilizer. On weakly and medium-solonetzic soils, it is recommended to apply gypsum: on slightly solonetzic soils it is 3-5 t/ha, on mediumalkaline soils it is 5-9 t/ha. In the absence of gypsum, it is recommended to use phosphogypsum in amount of $3-8 \mathrm{t} / \mathrm{ha}$. On salt licks of heavy texture, in order to improve the water-air regime and wash out the salts, it is necessary to arrange mole draining or inline ripping.

Along with the introduction of chemical ameliorants, deep soil cultivation is required in order to use calcium carbonates or gypsum of the soil itself (soil self-reclamation), the 
introduction of organic and mineral fertilizers, as well as grass sowing against the background of irrigation.

Crop rotation is one of the effective ways of soil desalinization and soil fertility management in rice agricultural landscapes.

As a result of widespread non-observance of scientifically grounded crop rotation in rice crop rotation (refusal to grow perennial grasses (lucerne), which is consequence of reducing livestock production at rice-growing enterprises. Economically viable alternative to lucerne in rice crop rotations is soybeans, whose plants have the ability to assimilate atmospheric nitrogen through symbiosis with nodule bacteria, i.e. increase soil fertility. During the growing season, under soybeans, biological nitrogen of up to $100 \mathrm{~kg} / \mathrm{ha}$ is accumulated in the soil. Soybeans are placed in those checks where the groundwater level is not higher than $40-50 \mathrm{~cm}$ from the soil surface and there is no flooding. In rotation, soybeans can withstand saturation up to $50 \%$ alternating with rice, i.e. it can be successfully cultivated in specialized short-rotation (4-field) crop rotations.

In the first year after soybeans, rice yields are 5.3\% lower than that of lucerne, and in the second year, these differences can be $10-15 \%$. The reason for the lower rice yields caused by the fact that, in comparison with lucerne soybeans, firstly, leaves less nutrients in the soil in the form of roots and crop residues and, secondly, having less developed root system, does not provide adequate improvement in aquatic-physical properties of the soil. This problem can be solved by phytomelioration and replacing soybeans in the second field with colza (Table 3). [25]

Table 3. Prospective schemes for 8 -field rice crop rotations

\begin{tabular}{|c|c|c|c|c|}
\hline \multirow{3}{*}{$\begin{array}{l}\begin{array}{l}\text { Field } \\
\text { number }\end{array} \\
1\end{array}$} & \multirow{3}{*}{$\begin{array}{l}\begin{array}{l}\text { Base } \\
\text { crop rotation }\end{array} \\
\text { Lucerne } \\
\end{array}$} & \multicolumn{3}{|c|}{ Promising crop rotations } \\
\hline & & \multicolumn{2}{|c|}{ at $62.5 \%$ saturation with rice } & \multirow{2}{*}{$\begin{array}{c}\text { at } 50 \% \text { saturation with rice } \\
\text { Soybean } \\
\end{array}$} \\
\hline & & Soybean & Soybean & \\
\hline 2 & Lucerne & Soybean & Rice & Soybean \\
\hline 3 & Rice & Rice & Rice & Rice \\
\hline 4 & Rice & Rice & Rice & Rice \\
\hline 5 & Rice & Rice & Rice & Soybean \\
\hline 6 & $\begin{array}{l}\text { Agro-reclamation } \\
\text { field }\end{array}$ & $\begin{array}{lr}\text { Occupied } & \text { fallow } \\
\text { soybean, } 50 \% \text { colza }) & (50 \%\end{array}$ & $\begin{array}{l}\text { Occupied fallow } \\
(50 \% \text { soybean })\end{array}$ & $\begin{array}{lr}\begin{array}{l}\text { Occupied fallow } \\
\text { soybean, } 50 \% \text { colza })\end{array} & (50 \% \\
\end{array}$ \\
\hline 7 & Rice & Rice & Rice & Rice \\
\hline 8 & Rice & Rice & Rice & Rice \\
\hline
\end{tabular}

When cultivated for grain or as green manure, winter colza acts as phytomeliorant. It develops powerful, deeply penetrating into the soil (up to $3 \mathrm{~m}$ ) tap root system, which piercing the soil improves its water and air permeability. It helps to improve the structure of soils, increases their fertility, clears weeds, significantly improves the phytosanitary state of the field. For 1 ha, winter colza leaves about 60 centners of root residues - more than winter wheat. The root secretions of colza are capable of converting phosphorus from hard-toreach forms into available ones for rice plants. Colza is the only crop that "pulls" potassium from the lower soil layers to the upper fertile one and transforms it into a form that is available for rice. With the observance of agricultural technology in rice crop rotations, it is possible to obtain colza yields up to 50 and more c/ha.

Winter colza can be used as green manure crop. In terms of fertilizing ability, the green mass of colza is close to manure. At the same time, growing it for green manure is much more economical and efficient. Plowing the green mass of colza at the rice-sowing farm on Chernoerkovskaya irrigation system in 2018 made it possible to obtain increase in the rice grain yield of $18.5 \mathrm{c} / \mathrm{ha}$. In the case when the green mass was used for fodder $(200 \mathrm{c} / \mathrm{ha})$, 
and the crop residues were plowed, the increase in the rice grain yield was only $8 \mathrm{c} / \mathrm{ha}$ [2324].

Colza is alternative source of organic fertilizers. 10-15 t/ha of dry matter of roots, leaves, straw returns to the soil, and another 10-20 tons of green biomass grows from selfseeding. After harvesting winter colza for seeds, 6-7 times more root residues remain in the soil than after grain crops. With them, up to $10 \mathrm{~kg} / \mathrm{ha}$ of nitrogen, phosphorus and potassium enter the soil. One ton of colza root residues in terms of their nutrient content is equivalent to 3.75 tonnes of manure.

Research shows that the use of colza as green manure is equivalent to the manure introduction, and the costs are 1.5-2 times lower. The biological activity of the soil increases by $10-15 \%$, the rice yield rises by $20 \%$. [21-22]

Colza, due to the content of allyl mustard oils in its biomass, has positive phytosanitary effect on the soil, reduces the incidence of root rot and other diseases in cereals.

Soybeans and colza, as intercrops of the rice crop rotation, are not only good precursors for the main crop, rice, but also contribute to increase in soil fertility.

\section{Conclusion}

Thus, the results of the survey of agricultural lands of Chernoerkovsk irrigation system have scientific and practical importance and allow differentiated approach to their use in the formation of measures that contribute to the soil fertility management at rice agricultural landscapes.The results of the study of the soil-reclamation state of rice agricultural landscapes showed that during the exploitation of Chernoerkovskaya rice irrigation system, their desalinization was observed, which was facilitated by percolative regime of rice fields under rice.

Monitoring of the hydrological and reclamation state made it possible to differentiate the exploited lands by salinity. The degree, type and causes of their salinity have been determined, the relationship between the salt regime of soils and the regime of the level and chemical composition of groundwater has been established; recommendations for managing the fertility of rice agricultural landscapes are given.

In addition, the proposed eight-field crop rotation for modern economic conditions with its saturation with colza and soybean crops will contribute to the creation of favorable conditions for microbiological processes in the soil, mineralization of organic substances, and improvement of the phytosanitary situation in rice agrobiocenoses.

\section{References}

1. Y. Zhou, L. Li, K. Lin, X.P. Zhu, W.P. Liu. Enantiomer separation of triazole fungicides by high-performance liquid chromatography. Chirality, 21, 421-427 (2009)

2. P. Xu, J. Diao, D. Liu, Z. Zhou. Enantioselective bioaccumulation and toxic effects of metalaxyl in earthworm Eisenia foetida. Chemosphere, 83, 1074-1079 (2011)

3. F. G. Iturburu, M. Zömisch, A. M. Panzeri, A. C. Crupkin, V. Contardo-Jara, S. Pflugmacher, M. L. Menone, Uptake, distribution in different tissues, and genotoxicity of imidacloprid in the freshwater fish Australoheros facetus Environ. Toxicol. Chem, 36, 699-708 (2017)

4. N. Mantzos, A. Karakitsou, S. Nikolaki, E. Leneti, I. Konstantinou, Dissipation and transport of quizalofop-p-ethyl herbicide in sunflower cultivation under field conditions. Environ. Sci. Pollut. Res., 23, 3481-3490 (2016) 
5. X. Chen, S. Yu, L. Han, S. Sun, Y. Zhi, W. Li. Residues and dissipation of the herbicide fenoxaprop-p-ethyl and its metabolite in wheat and soil. Bull. Environ. Contam. Toxicol., 87, 50-53(2011)

6. Y. Qi, D. Liu, M. Luo, X. Jing, P. Wang, Z. Zhou. Enantioselective degradation and chiral stability of the herbicide fluazifop-butyl in soil and water. Chemosphere, 146, 315-322 (2016)

7. L. Rong, X. Guo, K. Chen, J. Zhu, S. Li, J. Jiang, Isolation of an isocarbophosdegrading strain of Arthrobacter sp. scl-2 and identification of the degradation pathway. J. Microbiol. Biotechnol., 19, 1439-1446 (2009)

8. H. Zhang, X. Q. Wang, S. L. Zhuang, N. Jin, X. Y. Wang, M. R. Qian, H. Xu, P. P. Qi, Q. Wang, M. H. Wang, Enantioselective analysis and degradation studies of isocarbophos in soils by chiral liquid chromatography-tandem mass spectrometry. J. Agric. Food Chem., 60, 10188-10195 (2012)

9. W. X. Xie Jian, Jian-jun Tanf, Jia-en Zhang, L. Shi-ming, X. Chen, Conservation of traditional rice varieties in a globally important agricultural heritage system (GIAHS): rice-fish Co-culture, Agric. Sci. China, 10, 754-761 (2011)

10. M. A. Rahman, Integration of aquaculture with rice farming: a way to increase farm productivity, food security, livelihood improvement and better environment 6th Int'l Conference on Agriculture, Environment and Biological Sciences (ICAEBS'16), 8, 149-151 (2016)

11. T. Liu, J. Diao, S. Di, Z. Zhou, Bioaccumulation of isocarbophos enantiomers from laboratory-contaminated aquatic environment by tubificid worms Chemosphere, 124, 77-82 (2015)

12. M. Tian, Q. Zhang, X. Hua, B. Tang, B. Gao, M. Wang, Systemic stereoselectivity study of flufiprole: stereoselective bioactivity, acute toxicity and environmental fate, J. Hazard. Mater., 320, 487-494 (2016)

13. Z. Yao, M. Lin, M. Xu, T. Wang, X. Ping, S. Wu, Q. Wang, H. Zhang, Simultaneous enantioselective determination of isocarbophos and its main metabolite isocarbophos oxon in rice, soil, and water by chiral liquid chromatography and tandem mass spectrometry, J. Sep. Sci., 38, 1663-1672 (2015)

14. Y. Wang, D. Dai, Y. Yu, G. Yang, W. Shen, Q. Wang, H. Weng, X. Zhao, Evaluation of joint effects of cyprodinil and kresoxim-methyl on zebrafish, Danio rerio, J. Hazard. Mater., 352, 80-91 (2018)

15. M. G. Nillos, J. Gan, D. Schlenk, Chirality of organophosphorus pesticides: analysis and toxicity, J. Chromatogr. B, 878, 1277-1284 (2010)

16. N. Malysheva, A. Khadzhidi, E. Kuznetsov, N. Sharaby, A. Koltsov, Justification of elements of rice cultivation technology, E3S Web of Conferences, 175, 01006 (2020) INTERAGROMASH 2020 https://doi.org/10.1051/e3sconf/202017501006.

17. S. I. Kambulov, I. V. Bozhko, A. V. Olshevskaya, MATEC Web of Conferences, 224, 05022 (2018) https://doi.org/10.1051/matecconf/201822405022

18. A. Altybayev, A. Zhanbyrbayev, B. Meskhi, D. Rudoy, A. Olshevskaya, A. Prohorova, E3S Web of Conferences, 135, 01078 (2019) https://doi.org/10.1051/e3sconf/201913501078

19. G. Parkhomenko, S. Kambulov, A. Olshevskaya, A. Babadzhanyan, N. Gucheva, I. Mekhantseva, IOP Conf. Series: Earth and Environmental Science, 403, 012144 (2019) IOP Publishing doi:10.1088/1755-1315/403/1/012144 
20. V. Zhurba, Y. Chayka, N. Gucheva, D. Ushakov, N. Ugrekhelidze, N. Kulikova, M. Egyan, E3S Web of Conferences, 135, 01087 (2019) ITESE-2019 https://doi.org/10.1051/e3sconf/201913501087

21. I. Bozhko, G. Parkhomenko, S. Kambulov, A. Boyko, V. Kolodkin, M. Magomedov, D. Rudoy, E3S Web of Conferences, 175, 05025 (2020) INTERAGROMASH 2020 https://doi.org/10.1051/e3sconf/202017505025

22. G. Parkhomenko, I. Bozhko, S. Kambulov, A. Boyko, O. Polushkin, V. Lebedenko, A. Beskopilniy, A. Olshevskaya, E3S Web of Conferences, 175, 09006 (2020) INTERAGROMASH $2020 \mathrm{https} / / /$ doi.org/10.1051/e3sconf/202017509006

23. V. V. Ivanov, S. I. Popov, N. S. Dontsov, A. A. Kotesova, The oxide film formation under vibration processing in the high-resource parts manufacture in transport engineering. International Scientific Conference "Construction and Architecture: Theory and Practice for the innovation Development» (CATPID-2020): IOP Conference Series: Materials Science and Engineering, 913, 042056 (2020) doi:10.1088/1757-899X/913/4/042056

24. V. V. Ivanov, S. I. Popov, N. S. Dontsov, G. E. Ekinil, Ju. A. Oleynikova, Ju. N. Denisenko, Mechanical coating formed under conditions of vibration exposure. XIII International Scientific and Practical Conference "State and Prospects for the Development of Agribusiness - INTERAGROMASH 2020»: E3S Web of Conferences, 175, 05023 (2020) doi.org/10.1051/e3sconf/202017505023

25. V. V. Ivanov, S. I. Popov, Ju. V. Marchenko, E. V. Marchenko, N. S. Dontsov, S. A. Timofeev, Thickness of vibrational mechanochemical solid-lubricant coating in friction pairs of transport engineering products. XII International Scientific Conference on Agricultural Machinery Industry (INTERAGROMASH 2019): IOP Conference Series: Earth and Environmental Science, 403, 012115 (2019) doi:10.1088/1755-1315/403/1/012115 